\title{
KOMUNIKASI PENDIDIKAN MELALUI PELATIHAN KEWIRAUSAHAAN DI WILAYAH TINGGAL MAHASISWA PADA MASA PANDEMI COVID-19
}

\author{
Oleh \\ Yanti Setianti $^{1}$, Priyo Subekti ${ }^{2}$, \\ Rangga Saptya Mohamad Permana ${ }^{3}$, Heru Ryanto Budiana ${ }^{4}$ \\ 1,2,3,4 Universitas Padjadjaran, Bandung, Indonesia \\ ${ }^{1}$ yanti.setianti@unpad.ac.id, ${ }^{2}$ priyo.subekti@unpad.ac.id,

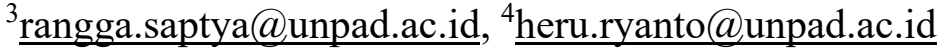

\begin{abstract}
Losing jobs, decreasing income and changing learning systems are problems faced by the community during the COVID-19 pandemic that can impact those who have children which is a college student. One of the efforts to raise awareness to survive in this epidemic is to try to foster an entrepreneurial spirit for the community, especially students, by carrying out educational communication through entrepreneurship training so that they can start a business that can generate income to help their parents pay for tuition fees and daily life. The purpose of this study was to determine students' knowledge of entrepreneurship, the skills of students in making entrepreneurship planning and the skills of students to do entrepreneurship. The method used in this research is descriptive, which provides an overview of the knowledge, planning and implementation of entrepreneurship by students on the islands of Java and Bali. The results showed that after training activities, students' knowledge of entrepreneurship increased, from not knowing entrepreneurship at all to knowing what was meant by entrepreneurship. Students' skills in planning entrepreneurship have increased, from not understanding at all about entrepreneurial planning to understanding and practicing entrepreneurial planning. Students' skills regarding the implementation of entrepreneurship have increased, from those who never imagined that one day they would be able to become entrepreneurs, to imagine what it would be like if they became entrepreneurs.
\end{abstract}

Keywords: COVID-19; Educational Communication; Planning; Enterpreneurship; College Student 
KOMUNIKASI PENDIDIKAN MELALUI PELATIHAN KEWIRAUSAHAAN

DI WILAYAH TINGGAL MAHASISWA PADA MASA PANDEMI COVID-19

\section{PENDAHULUAN}

Pandemi COVID-19 di berbagai

belahan dunia tentu memberikan

dampak yang besar di berbagai sektor

kehidupan. Di sektor ekonomi

misalnya penerapan Pembatasan

Sosial Berskala Besar (PSBB)

menyebabkan banyak orang terpaksa

menjalankan pekerjaannya dari rumah

atau Work From Home (WFH). Tak

sampai di situ, banyak pula yang

diberhentikan dari pekerjaannya

lantaran perusahaan mulai

kelimpungan untuk mempertahankan

bisnis di tengah kondisi yang carut

marut. Akibatnya, banyak orang harus

banting setir mencari sumber

penghasilan lain agar kebutuhan

tercukupi, salah satunya dengan

berwirausaha (Fadhila, 2020b).

Pandemi COVID-19 di seluruh

dunia, tidak terkecuali Indonesia, memberikan dampak luar biasa terhadap hampir seluruh sektor kehidupan,

termasuk

sektor

pendidikan dan sektor ekonomi.

Kehilangan pekerjaan, menurunnya

pendapatan dan berubahnya sistem

pendidikan menjadi pembelajaran

jarak jauh adalah persoalan yang

dihadapi masyarakat saat ini termasuk

mahasiswa. Upaya menumbuhkan

kesadaran untuk bertahan ditengah

suasana pendemi ini salah satunya

adalah mencoba menumbuhkan jiwa

kewirausahaan bagi masyarakat

khususnya mahasiswa dengan

menggunakan berbagai media

pendidikan.

Media pendidikan dalam sistem pembelajaran jarak jauh sekarang sudah banyak dilakukan, bisa menggunakan Google Classroom, bisa melakukan komunikasi bermedia konferensi video lewat aplikasi Zoom Meeting walaupun pasti memiliki keterbatasan atau melakukan webinar yang bisa diikuti 
KOMUNIKASI PENDIDIKAN MELALUI PELATIHAN KEWIRAUSAHAAN

DI WILAYAH TINGGAL MAHASISWA PADA MASA PANDEMI COVID-19

oleh semua mahasiswa sehingga kewirausahaan dibutuhkan media mereka dapat terterpa oleh informasi mengingat mahasiswa berada di tentang kewirausahaan. Terpaan tempat tinggal masing masing.

informasi atau pesan terjadi apabila Menurut McClelland salah satu seseorang itu membaca, menonton, faktor yang menyebabkan sebuah mendengar, dan kemudian timbul negara menjadi maju adalah ketika efek baik langsung maupun tidak jumlah wirausahawan yang terdapat langsung sehingga membentuk di negara tersebut berjumlah $2 \%$ dari persepsi dalam dirinya terhadap populasi penduduknya. Saat ini, informasi atau pesan yg menerpanya jumlah wirausaha yang terdapat di (Kriyantono, 2012).

Indonesia mencapai 400 ribu jiwa

Jiwa kewirausahaan mahasiswa atau kurang dari $1 \%$ populasi harus digali untuk menumbuhkan penduduk Indonesia yang berkisar sikap dan perilaku mau melakukan 200 juta jiwa. Kondisi ini sangat usaha dengan memanfaatkan potensiberbanding terbalik dengan yang potensi sumber daya alam dan terjadi di Amerika Serikat misalnya potensi-potensi sumber daya manusia yang memiliki jumlah wirausaha yang berada di sekitar tempat tinggal sebesar $11,5 \%$ dari populasi mahasiswa yang berada di Bandung, penduduknya atau negara tetangga Subang, Bekasi, Jakarta, Depok, yaitu Singapura dengan 7,2\% Sumedang, Majalengka, Serang, warganya bekerja sebagari wirausaha. Bogor, Tasikmalaya, Sukoharjo, Efeknya tidak mengherankan bila Sidoarjo dan Bali. Untuk kedua negara tersebut menjadi salah menyampaikan informasi mengenai satu negara dengan perkembangan 
KOMUNIKASI PENDIDIKAN MELALUI PELATIHAN KEWIRAUSAHAAN

DI WILAYAH TINGGAL MAHASISWA PADA MASA PANDEMI COVID-19

ekonomi termaju di dunia (Direktorat

Jenderal Pendidikan Tinggi, 2013).

Hendra Karunia sebagai

founder

DestinasiBandung.id

mengatakan "Kita tetap harus

mengembangkan strategi agar usaha

kita dapat bertahan, peluang bisnis

sebenarnya selalu ada dan masyarakat

perlu memikirkan strategi yang tepat

agar bisnis berjalan dengan baik.

Masyarakat dan mahasiswa dapat

memanfaatkan media sosial sebagai

media promosi. Selain barang,

masyarakat bisa menjual jasa dengan

memanfaatkan potensi atau hobi yang

dimiliki. "Intinya, kita harus cepat

beradaptasi,” katanya (Fadhila,

2020a).

Kewirausahaan yang diarahkan

untuk menumbuhkan jiwa dan

semangat kemandirian dengan

menggali potensi usaha ekonomi yang

ada disekitar wilayah tinggalnya,

dengan harapan dapat memberikan hasil secara ekonomi. Pentingnya memberikan komunikasi pendidikan untuk melatih jiwa kewirausaan bagi mahasiswa untuk menggali potensi kewirausahaan yang ada di sekitar tempat tinggal mahasiswa. Dengan demikian melalui pelatihan keterampilan wirausaha yang dilakukan melalui komunikasi pendidikan diharapkan dapat memasyarakatkan dan membudayakan nilai-nilai kewirausahaan pada mahasiswa untuk memulai usaha di lingkungan tempat tinggal masing masing.

Pelatihan keterampilan memiliki peranan dalam meningkatkan keterampilan wirausaha. Tidak optimalnya kegiatan yang terjadi dalam pelatihan menimbulkan ketidakmaksimalan peningkatan kemampuan wirausaha peserta pelatihan. Jika kemampuan wirausaha peserta pelatihan 
KOMUNIKASI PENDIDIKAN MELALUI PELATIHAN KEWIRAUSAHAAN

DI WILAYAH TINGGAL MAHASISWA PADA MASA PANDEMI COVID-19

diharapkan dapat meningkat secara Mahasiswa merupakan individu-

maksimal maka kegiatan atau proses individu yang tentunya banyak

pelatihan yang dijalani peserta mempunyai perbedaan antara satu

pelatihan harus dapat diikuti secara dengan lainnya. Walaupun demikian, optimal.

dari heterogenitas di antara mereka itu

Jika melihat jumlah kebutuhan dapat dicari homogenitas atau

wirausaha baru untuk memposisikan persamaannya, yaitu di antaranya

Indonesia sebagai negara maju, adalah kesamaan dalam pemikiran

setidaknya masih butuh waktu 25 akan kebutuhan informasi dan

tahun lagi untuk mencapainya kebutuhan ekonomi. Salah satu usaha

(Rukka, 2011). Estimasi waktu yang untuk memenuhi kebutuhan informasi

cukup lama tersebut menuntut perlu dan ekonomi mahasiswanya, maka

segera diupayakan langkah-langkah harus diadakan pelatihan

agar jumlah wirausaha baru dapat kewirausahaan untuk menjadikan

bertambah dengan waktu pencapaian mahasiswa menjadi berdaya sehingga

yang relatif singkat. Salah satu bisa menciptakan lapangan kerja

langkah yang dapat dilakukan adalah sendiri setelah mereka lulus. Sehingga

dengan penciptaan wirausaha baru mereka tidak tergantung pada orang

yang berasal dari mahasiswa dan lain untuk mendapatkan pekerjaan

lulusan perguruan tinggi (Direktorat jika mereka tidak punya biaya untuk

Jenderal Pendidikan Tinggi, 2013). melanjutkan kuliah ke jenjang yang

Untuk mewujudkan mahasiswa lebih tinggi

menjadi seorang wirausahawan tidak

mudah untuk dilaksanakan. 
KOMUNIKASI PENDIDIKAN MELALUI PELATIHAN KEWIRAUSAHAAN

DI WILAYAH TINGGAL MAHASISWA PADA MASA PANDEMI COVID-19

PERUMUSAN MASALAH

Berdasarkan uraian di atas maka

masalah dapat dirumuskan sebagai

berikut: "Bagaimana Komunikasi

Pendidikan Melalui Pelatihan

Kewirausahaan di Wilayah Tinggal

Mahasiswa Pada Masa Pandemi

COVID-19?". Sedangkan identifikasi

masalah dapat diuraikan sebagai

berikut:

1. Bagaimana

pengetahuan

mahasiswa tentang kewirausahaan $?$

2. Bagaimana

keterampilan

mahasiswa dalam merencanakan

kewirausahaan?

3. Bagaimana

keterampilan

mahasiswa dalam melaksanakan

kewirausahaan?

KAJIAN PUSTAKA

Komunikasi Pendidikan

Komunikasi

pendidikan

merupakan proses komunikasi yang unik karena didalamnya ada dimensi edukatif selain menyampaikan pesan yang berupa materi pembelajaran. Komunikasi pendidikan bukan sekedar komunikasi yang berlangsung dengan latar pembelajaran atau pendidikan melainkan didalamnya terkandung nilai-nilai pendidikan. Dalam proses pembelajaran pasti didalamnya ada komunikasi dalam setiap interaksi edukasi akan berlangsung proses komunikasi. Komunikasi antara anak dan orang tua dalam pembelajaran di rumah atau guru dan siswa di sekolah serta dosen dan mahasiswa di Perguruan tinggi (Iriantara \& Syarifudin, 2013: 72).

Proses pembelajaran akan menghasilkan model pembelajaran yang bergerak dari ranah yang sama. Model ini berupaya memberi perhatian yang khusus dan mengoptimalkan kemampuan peserta didik melalui pendekatan psikologi 
KOMUNIKASI PENDIDIKAN MELALUI PELATIHAN KEWIRAUSAHAAN

DI WILAYAH TINGGAL MAHASISWA PADA MASA PANDEMI COVID-19

belajar, teori belajar, komunikasi yang baik dan terencana. Dengan pembelajaran dan rekayasa hasil demikian perlu dilakukan sebuah inovasi teknologi komunikasi dan pendalaman dalam melakukan informasi (Darmawan, 2009: 29). perencanaan pembelajaran. Hal Komunikasi pendidikan adalah tersebut ditujukan agar kompetensi “aspek komunikasi dalam dunia dapat terwujud dengan proses yang pendidikan atau komunikasi yang tepat serta dapat dipetakan dengan terjadi pada bidang pendidikan”. pemetaan yang jelas (Bunyamin \& Dengan demikian, posisi komunikasi Purnomo, 2017: 5).

hanya sebagai 'alat' yang berfungsi Dalam pelaksanaan pendidikan bisa diupayakan untuk membantu formal dan non formal, peranan memecahkan masalah-masalah komunikasi menjadi unsur yang pendidikan. Komunikasi dalam dominan. Adapun bentuk komunikasi pendidikan merupakan unsur yang pendidikan dalam konteks ini yaitu sangat penting kedudukannya. kegiatan instruksional dalam proses Bahkan mempunyai peranan dalam pendidikan. Yusup (2010) lebih menentukan keberhasilan suatu lanjut, menjelaskan bahwa proses pendidikan. Orang sering mengatakan instruksional itu sendiri merupakan bahwa tinggi rendahnya suatu capaian peristiwa komunikasi yang dirancang mutu pendidikan dipengaruhi pula khusus untuk tujuan perubahan oleh faktor komunikasi (Yusup, perilaku pada pihak sasaran (peserta 2010). didik) secara tuntas sesuai dengan Kondisi ideal dalam kemampuan, minat, dan nilai-nilai pembelajaran perlu melalui proses yang dianutnya. Di dalam proses 
KOMUNIKASI PENDIDIKAN MELALUI PELATIHAN KEWIRAUSAHAAN

DI WILAYAH TINGGAL MAHASISWA PADA MASA PANDEMI COVID-19

pengubah perilaku individu, faktor

komunikasi ini sama-sama

mempunyai kedudukan yang amat

menentukan.

Efek yang terjadi akan dapat terlihat pada setiap individu, apakah mengalami perubahan sikap dan perilaku atau tidak.

Sikap memiliki tiga komponen, yaitu: (1) Komponen kognisi yang hubungannya dengan beliefs, ide dan konsep. Komponen kognitif dapat disamakan dengan pandangan (opini), terutama apabila menyangkut masalah yang kontroversial;

Komponen afeksi yang menyangkut emosional seseorang. Komponen afektif merupakan perasaan individu terhadap objek sikap dan menyangkut masalah emosi. Aspek emosional inilah yang biasanya berakar paling dalam sebagai komponen sikap dan merupakan aspek yang paling bertahan terhadap pengaruh-pengaruh yang mungkin akan mengubah sikap seseorang; dan (3) Komponen konasi yang merupakan kecenderungan bertingkah laku. Komponen konatif atau komponen perilaku berisi tendensi atau kecenderungan untuk bertindak atau untuk bereaksi terhadap sesuatu dengan cara- cara tertentu. Komponen ini didasari oleh asumsi bahwa kepercayaan dan perasaan banyak mempengaruhi perilaku. Pengertian kecenderungan berperilaku menunjukkan bahwa komponen konatif meliputi bentuk perilaku yang tidak hanya dapat dilihat secara langsung saja, akan tetapi meliputi pula bentuk- bentuk perilaku yang berupa pernyataan atau perkataan yang diucapkan seseorang. Sikap pada hakikatnya adalah kecenderungan perilaku seseorang terhadap lingkungannya. Sikap juga dapat diartikan sebagai reaksi 
KOMUNIKASI PENDIDIKAN MELALUI PELATIHAN KEWIRAUSAHAAN

DI WILAYAH TINGGAL MAHASISWA PADA MASA PANDEMI COVID-19

seseorang atas stimulus yang datang

(Umniyati \& Hadisiwi, 2017).

Beberapa orang menganggap bahwa sikap terdiri dari kognitif, afektif dan behavioral.dalam buku psikologi komunikasi Jalaludin

Rahmat mengemukakan bahwa sikap dipandang dalam komponen afekifnya karena komponen kognitif dimasukan dalam konsep kepercayaan, komponen behavioral dimasukan dalam faktor sosiopsikologis konatif yang terdiri dari kebiasaan dan kemauan. (Rakhmat, 2018:50)

\section{Kewirausahaan}

Kewirausahaan adalah suatu ilmu yang mengkaji tentang pengembangan dan pembangunan semangat kreativitas serta berani menanggung resiko terhadap pekerjaan yang dilakukan demi mewujudkan hasil karya tersebut (Fahmi, 2014; 1). Kewirausahaan adalah kemampuan untuk melihat, dan menilai kesempatan-kesempatan bisnis, mengumpulkan sumbersumber data yang dibutuhkan guna mengambil keuntungan daripadanya dan mengambil tindakan yang tepat guna dan sukses (Daryanto, 2012: 5).

Wirausaha dijelaskan oleh para ahli melalui berbagai definisi. Wirausaha adalah wadah bagi kemandirian, wadah belajar sekaligus wadah mengeksplorasi berbagai hal terkait kapasitas dan kapabilitas masyarakat untuk menghadirkan kemajuan bagi diri dan lingkungannya (Purnomo, 2020: 7).

Berwirausaha mampu mengubah perilaku, namun ia tidak akan bisa bertahan lama kalau tidak ada ekosistem yang membina, menggerakkan dan mengarahkannya (Purnomo \& Adenita, 2020: 4). Dari sisi pembentukan karakter seorang wirausaha/enterpreneur, perguruan 
KOMUNIKASI PENDIDIKAN MELALUI PELATIHAN KEWIRAUSAHAAN

DI WILAYAH TINGGAL MAHASISWA PADA MASA PANDEMI COVID-19

tinggi sudah seharusnya menciptakan

atmosfer yang dapat mendorong sikap

mandiri bagi sivitas akademika. Hal

ini dapat dicapai melalui; 1)

Mengembangkan dan membiasakan

unjuk kerja yang mengedepankan ide

kreatif dalam berpikir dan sikap

mandiri bagi mahasiswa dalam proses

pembelajaran (menekankan model

latihan, tugas mandiri, problem

solving, cara mengambil keputusan,

menemukan peluang, dan seterusnya);

2) Menanamkan sikap dan perilaku

jujur dalam komunikasi dan bertindak

dalam setiap kegiatan pengembangan,

pendidikan, dan pembelajaran sebagai

modal dasar dalam membangun

mental entrepreneur pada diri

mahasiswa; dan 3) Para praktisi

pendidikan juga perlu sharing dan

memberi support atas komitmen

pendidikan mental entrepreneurship

ini kepada lembaga-lembaga terkait

dengan pelayanan bidang usaha yang muncul di masyarakat agar benarbenar berfungsi dan benar- benar menyiapkan kebijakan untuk mempermudah dan melayani masyarakat (Direktorat Jenderal Pendidikan Tinggi, 2013).

Identitas baru sebagai

wirausaha yang memiliki dampak manfaat bagi masyarakat banyak menjadi ukuran hal baru yang keren bagi generasi milenial. Generasi muda saat ini akan memilih untuk berperan bagi masyarakat dengan idealismenya melalui beragam bisnis yang mereka selenggarakan (D. Purnomo \& Kurniawan, 2017).

\section{METODE PENELITIAN}

Metode penelitian yang digunakan oleh peneliti yakni metode deskriptif dengan sifat data kualitatif yang mencari teori, bukan menguji teori atau bisa juga disebut sebagai hypothesis generating bukan 
KOMUNIKASI PENDIDIKAN MELALUI PELATIHAN KEWIRAUSAHAAN

DI WILAYAH TINGGAL MAHASISWA PADA MASA PANDEMI COVID-19

hypothesis testing. Ciri lain metode

deskriptif-kualitatif

adalah

menitikberatkan pada observasi dan

suasana alamiah (natural setting)

dimana penulis bersifat sebagai

pengamat (Ardianto, 2011).

Pendekatan yang digunakan

dalam peneltian ini adalah pendekatan

kualitatif. Denzin dan Lincoln mengungkapkan bahwa penelitian

pendekatan kualitatif merupakan

penelitian yang menggunakan latar

ilmiah, dengan maksud menafsirkan

fenomena yang terjadi dan dilakukan

dengan jalan melibatkan berbagai

metode yang ada (Moleong, 2010).

Pendekatan ini memberi kemudahan

bagi peneliti untuk merekam,

memantau, dan mengikuti proses

suatu peristiwa atau kegiatan sebuah

organisasi sebagaimana adanya dalam

suatu kurun waktu tertentu dan

selanjutnya diinterpretasikan untuk

menjawab masalah penelitian.
Sebagaimana dijelaskan oleh Locke,

Spriduso dan Silferman (Creswell,

2013).

"Qualitative research is interpretative research as such the blases, values and judgement of the researches become stated explicity in the research report. Such openness is considered to be useful and positive"

Penelitian kualitatif adalah penelitian interpretatif dengan demikian nilai-nilai dan penilaian dari penelitian menjadi menyatakan kejelasan dalam laporan penelitian. Keterbukaan seperti itu dianggap bermanfaat dan positif. Karakteristik penelitian kualitatif seperti yang dinyatakan oleh Bogdan dan Biklen antara lain:

“(1) dilakukan pada kondisi yang alamiah, langsung ke sumber data dan peneliti adalah instrumen kunci; (2) bersifat deskriptif yang dimana data yang terkumpul berbentuk katakata atau gambar, sehingga tidak menekankan pada angka; (3) lebih menekankan pada proses daripada produk atau outcome; (4) melakukan analisis data secara induktif; dan (5) lebih menekankan makna." (Sugiyono, 2011) 
KOMUNIKASI PENDIDIKAN MELALUI PELATIHAN KEWIRAUSAHAAN

DI WILAYAH TINGGAL MAHASISWA PADA MASA PANDEMI COVID-19

\section{HASIL PENELITIAN DAN}

\section{PEMBAHASAN}

Hasil penelitian menunjukkan untuk menumbuhkan jiwa kewirausahaan maka harus diketahui dulu pengetahuan mahasiswa tentang kewirausahaan seperti apa. Berdasarkan hasil penelitian sebagian besar mahasiswa belum mengetahui pengertian dari kewirausahaan karena mayoritas mahasiswa tidak mendapatkan matakuliah kewirausahaan di kampusnya. Setelah mengikuti pelatihan kewirausahaan sebagian besar mahasiswa menjadi tahu dan mengerti apa yang dimaksud dengan kewirausahaan, bagaimana cara menggali potensi usaha yang ada di daerah tempat tinggal mereka.

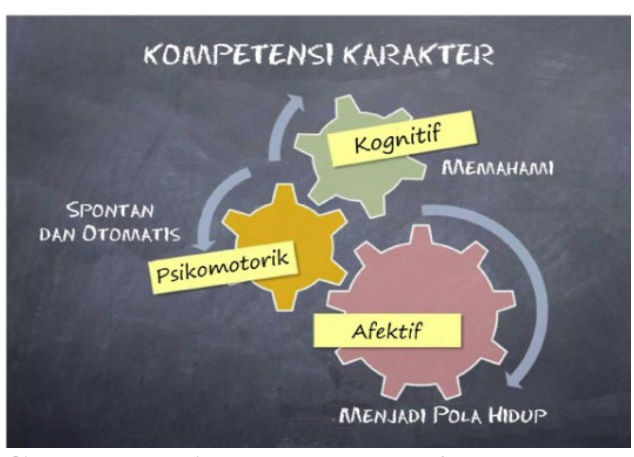

Gambar 1 Kompetensi karakter Kewirausahaan Sumber Modul kewirausahan (Direktorat Jenderal Pendidikan Tinggi, 2013)

Mahasiswa mampu memahami pentingnya karakter wirausaha dan secara spontan dan otomatis dapat bersikap seperti wirausahawan dan berdasarkan pemahamannya menjadikan karakter tersebut sebagai pola hidup dalam kesehariannya. Sebelum berbicara mengenai wirausaha, ada baiknya mahasiswa diperkenalkan dan disadarkan tentang pentingnya mereka memiliki tujuan hidup atau impian. Hal ini sangat penting ditekankan di awal pelatihan agar mahasiswa memiliki semangat untuk berprestasi dan bersungguhsungguh meraih impiannya. Sangat disayangkan bila seorang mahasiswa 
KOMUNIKASI PENDIDIKAN MELALUI PELATIHAN KEWIRAUSAHAAN

DI WILAYAH TINGGAL MAHASISWA PADA MASA PANDEMI COVID-19

baru menyadari untuk apa mereka yang kokoh yang dibangun tidak sebenarnya kuliah, dan lain-lain dalam waktu singkat. Urgensi impian setelah mereka lulus. Kebanyakan ini semakin penting mengingat resiko lulusan perguruan tinggi menjadi dari wirausaha ini tidaklah kecil, bila pengangguran adalah akibat mereka mahasiswa tidak memiliki impian tidak memiliki impian dan tidak yang kokoh maka sangat mungkin bersungguh-sungguh untuk baginya untuk cepat dirumuskan, meraihnya. Oleh karena itu kegiatan maka kita akan merujuk kepada awal adalah penekanan mengenai sebuah konsep yang bernama urgensi impian dalam hidup.

SMART (Direktorat Jenderal Syaefuddin (2003) mengatakan Pendidikan Tinggi, 2013).

bahwa seharusnya para lulusan Sukses itu bukanlah sebuah melihat kenyataan bahwa lapangan kerja yang ada tidak memungkinkan untuk menyerap seluruh lulusan perguruan tinggi di Indonesia, para Apakah impian yang SMART itu? lulusan perguruan tinggi mulai Impian yang SMART adalah Impian memilih berwirausaha sebagai pilihan yang: Specific artinya Anda harus karirnya, mengingat potensi yang ada jelas mengenai apa yang anda di negeri ini sangat kondusif untuk inginkan, dengan demikian anda akan melakukan wirausaha. Ilik (2010) lebih mudah dalam membuat mengatakan bahwa, untuk memulai perencanaan. Dengan demikian, menjadi seorang wirausaha, setiap istilah "Saya memiliki impian mahasiswa harus memiliki impian menjadi orang sukses" diganti dengan 
KOMUNIKASI PENDIDIKAN MELALUI PELATIHAN KEWIRAUSAHAAN

DI WILAYAH TINGGAL MAHASISWA PADA MASA PANDEMI COVID-19

misalnya; "Saya memiliki impian

untuk menjadi seorang manajer

pemasaran di PT X dengan

penghasilan Rp X” atau "Saya ingin

menjadi seorang wirausahawan di

bidang $\mathrm{X}$ dengan penghasilan sebesar

Rp X dan lainnya. Measurable artinya

impian haruslah terukur. Dengan

demikian, anda akan tahu kapan

impian anda telah tercapai.

Achieveble artinya Impian anda harus

dapat anda raih. Jika impian itu terlalu

besar, anda perlu memecah impian itu

menjadi impian yang lebih kecil dulu

sebagai langkah awal atau bagian

dalam pencapaian impian besar.

Realistic artinya, impian Anda harus

masuk akal. Makna masuk akal ini

biasanya dikaitkan dengan

kemampuan/ketersediaan sumber

daya yang dimiliki. Time Bond,

Impian haruslah memiliki garis waktu

yang jelas kapan impian tersebut

ingin Anda raih. Misalnya: "Saya memiliki impian mendirikan sekolah bagi anak-anak yang tidak mampu 10 tahun dari sekarang" (Direktorat Jenderal Pendidikan Tinggi, 2013).

Sikap dasar yang harus disadari terlebih dahulu adalah, sukses itu bukanlah sebuah kebetulan, namun sukses adalah by Design. Sikap memiliki tiga komponen, yaitu: (1) Komponen kognisi yang hubungannya dengan beliefs, ide dan konsep. Komponen kognitif dapat disamakan dengan pandangan (opini), terutama apabila menyangkut masalah yang kontroversial; (2) Komponen afeksi yang menyangkut emosional seseorang. Komponen afektif merupakan perasaan individu terhadap objek sikap dan menyangkut masalah emosi. Aspek emosional inilah yang biasanya berakar paling dalam sebagai komponen sikap dan merupakan aspek yang paling bertahan terhadap pengaruh-pengaruh 
KOMUNIKASI PENDIDIKAN MELALUI PELATIHAN KEWIRAUSAHAAN

DI WILAYAH TINGGAL MAHASISWA PADA MASA PANDEMI COVID-19

yang mungkin akan mengubah sikap

seseorang; dan (3) Komponen konasi

yang merupakan kecenderungan

bertingkah laku. Komponen konatif

atau komponen perilaku berisi

tendensi atau kecenderungan untuk

bertindak atau untuk bereaksi

terhadap sesuatu dengan cara- cara

tertentu. Komponen ini didasari oleh

asumsi bahwa kepercayaan dan

perasaan banyak mempengaruhi

perilaku. Pengertian kecenderungan

berperilaku menunjukkan bahwa

komponen konatif meliputi bentuk

perilaku yang tidak hanya dapat

dilihat secara langsung saja, akan

tetapi meliputi pula bentuk- bentuk

perilaku yang berupa pernyataan atau

perkataan yang diucapkan seseorang.

Sikap pada hakikatnya adalah

kecenderungan perilaku seseorang

terhadap lingkungannya. Sikap juga

dapat diartikan sebagai reaksi seseorang atas stimulus yang datang

(Umniyati \& Hadisiwi, 2017).

Beberapa orang menganggap bahwa sikap terdiri dari kognitif, afektif dan behavioral. Dalam buku psikologi komunikasi Jalaludin rahmat mengemukakan bahwa sikap dipandanf dalam komponen afekifnya karena komponen kognitif dimasukan dalam konsep kepercayaan, komponen behavioral dimasukan dalam faktor sosiopsikologis konatif yang terdiri dari kebiasaan dan kemauan. (Rakhmat, 2018:50)

Sebagian besar informan setelah mengikuti pelatihan kewirausahaan menjadi paham dan mengerti bagaimana mereka harus membuat perencanaan terlebih dahulu sebelum mereka membuat sebuah produk untuk usaha. Proses kewirausahaan dari beberapa konsep yang ada, setidaknya terdapat enam hakekat 
KOMUNIKASI PENDIDIKAN MELALUI PELATIHAN KEWIRAUSAHAAN

DI WILAYAH TINGGAL MAHASISWA PADA MASA PANDEMI COVID-19

penting kewirausahaan. Di antaranya:

1) Kewirausahaan adalah suatu nilai yang diwujudkan dalam perilaku yang dijadikan dasar sumber daya, tenaga penggerak, tujuan, siasat, kiat, proses, dan hasil bisnis; 2) Kewirausahaan adalah suatu kemampuan untuk menciptakan sesuatu yang baru dan berbeda (ability to create the new and different); 3) Kewirausahaan adalah suatu proses penerapan kreativitas dan inovasi dalam memecahkan persoalan dan menemukan peluang untuk memperbaiki kehidupan; 4) Kewirausahaan adalah suatu nilai yang diperlukan untuk memulai suatu usaha (start-up phase) dan perkembangan usaha (venture growth); 5) Kewirausahaan adalah suatu proses dalam mengerjakan sesuatu yang baru (creative), dan sesuatu yang berbeda (inovative) yang bermanfaat memberi nilai lebih; dan 6) Kewirausahaan adalah usaha menciptakan nilai tambah dengan jalan mengkombinasikan sumbersumber melalui cara-cara baru dan berbeda untuk memenangkan persaingan. Nilai tambah tersebut dapat diciptakan dengan cara mengembangkan teknologi baru, menemukan pengetahuan baru, menemukan cara baru untuk menghasilkan barang dan jasa yang baru yang lebih efisien, memperbaiki produk dan jasa yang sudah ada, dan menemukan cara baru untuk memberikan kepuasan kepada konsumen (Direktorat Jenderal Pendidikan Tinggi, 2013).

Berdasarkan keenam konsep diatas, secara ringkas kewirausahaan dapat didefinisikan sebagai sesuatu kemampuan kreatif dan inovatif (create new and different) yang dijadikan kiat, dasar, sumber daya, proses dan perjuangan untuk menciptakan nilai tambah barang dan 
KOMUNIKASI PENDIDIKAN MELALUI PELATIHAN KEWIRAUSAHAAN

DI WILAYAH TINGGAL MAHASISWA PADA MASA PANDEMI COVID-19

jasa yang dilakukan dengan untuk mendapatkan keuntungan baik

keberanian untuk menghadapi risiko. secara materil maupun secara moril

Sebelum mahasiswa memulai dengan memanfaatkan sumber daya

berwirausaha maka ada beberapa hal alam dan sumber daya manusia yang

yang harus dipersiapkan diantaranya ada di tempat tinggal masing-masing.

adalah Pilih bidang usaha yang harus Ada yang akan memulai usaha

diminati oleh mahasiswa dan membuat keripik dari singkong, ada

memiliki hasrat dan pengetahuan di yang akan membuat usaha membuat

dalamnya. Kemudian perluas dan keripik dari pisang dengan berbagai

perbanyak jaringan bisnis dan rasa ada yang akan memulai lagi

pertemanan. Pilihlah keunikan dan usaha membuat kue yang sebelumnya

nilai unggul dalam produk atau jasa pernah dilakukan ketika mereka

anda. Tentukan, apakah ingin sedang kuliah. Semua mahasiswa

bersaing berdarah-darah di usaha web tampak bersemangat dan antusias

murah meriah, atau akan spesifik mewujudkan keinginan mereka untuk

kepada desainnya, atau akan spesifik mulai dan melanjutkan berwirausaha

kepada faktor keamanannya atau dengan mengikuti ketentuan-

kepada tingkat kesulitan dan ketentuan yang harus diperhatikan

kompleksitas pengelolaan ketika akan memulai wirausaha.

databasenya. Jaga kredibilitas dan Hendra karunia sebagai founder

brand image. destinasibandung.id mengungkapkan

Setelah mengikuti pelatihan Intinya, pada masa pandemi ini, kita

kewirausahaan hampir semua tidak perlu khawatir dan takut untuk

mahasiswa mau melakukan wirausaha memulai usaha, justru sekarang bisa 
KOMUNIKASI PENDIDIKAN MELALUI PELATIHAN KEWIRAUSAHAAN

DI WILAYAH TINGGAL MAHASISWA PADA MASA PANDEMI COVID-19

dijadikan sebagai momen yang tepat

bagi kita untuk mulai berwirausaha

(Fadhila, 2020a).

Kiat memulai wirausaha juga dapat diadopsi menurut seorang pakar bisnis sekaligus motivator yaitu Tum

Desem Waringin. Berikut ini adalah langkah- langkah teknis yang dapat dilakukan untuk memulai bisnis : 1) Bangun Ide bisnis dengan menulis Impian dan hobby kita. Tuliskan sepuluh mimpi dan hobby kita, lalu seleksi menjadi tiga yang paling membuat kita sangat ambisius dan enjoy untuk menjalankannya. Seleksi lagi menjadi satu mimpi yang membuat kita menjadi harus untuk mewujudkannya. Sehingga satu mimpi tersebut benar-benar dijadikan sebagai Visi/Goal/Target yang harus diraih; 2). Berikan alasan yang sangat kuat untuk mewujudkan mimpi tersebut. Bayangkan kenikmatan apa yang akan kita dapat apabila mimpi tersebut terwujud dan kesengsaraan apa yang akan kita terima kalau mimpi tersebut tidak terwujud; 3) Mulai lah untuk mewujudkan mimpi tersebut dengan bertindak dan cari tema yang tepat dan tulis misi / Langkah pencapaian dan tuangkan menjadi konsep usaha yang jelas; 4) Lakukan riset baik di internet maupun di kenyataan sehari-hari, Visi dan Misi yang kita tulis harus terdefinisi dengan jelas, specific dan marketabel sesuai bidangnya; 5) Tuliskan dan rancang strategi yang akan dijalankan; 6) gunakan faktor pengungkit OPM (Other People's Money),OPE (Other People's Experience), OPI (Other People Idea) , OPT (Other People's Time), OPW (other People's Work); 7) Cari pembimbing (pilih yang sudah sukses di bidang tersebut), untuk pembanding dan mengurangi resiko kegagalan dalam melakukan langkah- 
KOMUNIKASI PENDIDIKAN MELALUI PELATIHAN KEWIRAUSAHAAN

DI WILAYAH TINGGAL MAHASISWA PADA MASA PANDEMI COVID-19

langkah pencapaian tujuan tersebut; mengikuti pelatihan ini menjadi

8) Buatlah sebuah TEAM yang meningkat, dari yang tidak tahu sama kompak untuk membantu sekali mengenai wirausaha menjadi mewujudkan goal tersebut $\mathrm{T}=$ tahu apa yang dimaksud dengan Together $\mathrm{E}=$ Everybody $\mathrm{A}=$ Achieve $\quad$ kewirausahaan. $\quad$ Keterampilan $\mathrm{M}=$ Miracle; 9) Optimalkan mahasiswa dalam merencanakan jaringan, relasi dan network yang kita kewirausahaan setelah mengikuti punya untuk mencapai tujuan/visi kita pelatihan ini menjadi meningkat, dari tersebut; 10) Buat jaringan baru yang yang tidak mengerti sama sekali tak terhingga dengan membuat relasi mengenai perencanaan wirausaha dan silaturahmi sebanyak-banyaknya; menjadi mengerti dan 11) Gunakan alat bantu untuk mempraktekkan membuat mempercepat pencapaian misal perencanaan wirausaha. Keterampilan website, jejaring sosial, mahasiswa mengenai pelaksanaan advertisement, promosi; dan 12). Buat wirausaha setelah mengikuti pelatihan sistem yang ideal untuk bisnis ini menjadi meningkat, dari yang tersebut. $\mathrm{S}=$ Save, $\mathrm{Y}=$ Your, $\mathrm{S}=$ Self, tidak pernah membayangkan suatu $\mathrm{T}=$ Timing, $\quad \mathrm{E}=$ Energy, $\mathrm{M}=$ Money $\quad$ saat mereka akan bisa wirausaha (Direktorat Jenderal Pendidikan menjadi terbayangkan bagaimana Tinggi, 2013). nantinya kalau mereka jadi pengusaha.

\section{SIMPULAN}

Pengetahuan mahasiswa mengenai kewirausahaan setelah 
KOMUNIKASI PENDIDIKAN MELALUI PELATIHAN KEWIRAUSAHAAN

DI WILAYAH TINGGAL MAHASISWA PADA MASA PANDEMI COVID-19

\section{DAFTAR PUSTAKA}

Ardianto, E. (2011). Metode Penelitian untuk Public Relations: Kuantitatif dan Kualitatif. Simbiosa Rekatama Media.

Bunyamin, A., \& Purnomo, D. (2017). Entrepreneur Speak Up. Bitread Publishing.

Creswell, J. W. (2013). Qualitative Inquiry \& Research Design. Sage Publication.

Darmawan, D. (2009). Komunikasi Pembelajaran. Humaniora.

Daryanto. (2012). Pendidikan Kewirausahaan. GAVA MEDIA.

Direktorat Jenderal Pendidikan Tinggi. (2013). Modul Pembelajaran Kewirausahaan. Kementrian Pendidikan dan Kebudayaan.

Fadhila, A. (2020a). Mengubah Strategi Wirausaha di Masa Pandemi COVID-19. bagikanberita.com.

Fadhila, A. (2020b). Ubah Strategi Agar Tak "Mati" Di Masa Pandemi. destinasibandung.co.id.

Fahmi, I. (2014). Kewirausahaan: Teori, Kasus dan Solusi. Alfabeta.

Iriantara, Y., \& Syarifudin, U. (2013). Komunikasi Pendidikan. Simbiosa Rekatama Media.
Kriyantono. (2012). Teknik Praktis Riset komunikasi. Kencana.

Moleong, L. J. (2010). Metodologi Penelitian Kualitatif. PT Remaja Rosdakarya.

Purnomo, D., \& Kurniawan, I. A. K. (2017). Sociopreneur Milenial : Bisnis Berbasis Kolaborasi antara Desa dan Kota. Bitread Publishing.

Purnomo, I. D. (2020). 99 Vitamin Nutrisi Untuk Proses Kreatif di Era Disrupsi. Bitread Publishing.

Purnomo, I. D., \& Adenita. (2020). Jangan Lelah Berproses; Sociopreneur. PT.Serambi Ilmu Semesta.

Rakhmat, J. (2018). Psikologi Komunikasi. Simbiosa Rekatama Media.

Sugiyono. (2011). Memahami Penelitian Kualitatif. CV. Alfabeta.

Umniyati, N., \& Hadisiwi, P. (2017). Pengaruh Terpaan Informasi Riset Melalui Website www.ppet.lipi.go.id Terhadap Sikap Mahasiswa Mengenai Penelitian. Jurnal Kajian Komunikasi, 5(1), 111-120. https://doi.org/https://doi.org/10. 24198/jkk.v5i1.9076

Yusup, P. M. (2010). Komunikasi Instruksional: Teori Dan Praktik. Bumi Aksara. 